\title{
Analysis of Teachers' Attitude towards Internet Use: Example of Chemistry Teachers
}

\author{
Mehmet Tekerek ${ }^{1}$, Orhan Ercan ${ }^{2}$ \\ ${ }^{1}$ Computer Education and Instructional Technology Department, Kahramanmaraş Sütçüimam University, \\ Kahramanmaraș, Turkey \\ ${ }^{2}$ Elementary Science Education Department, Kahramanmaraş Sütçüimam University, Kahramanmaraş, Turkey \\ Email: tekerek@ksu.edu.tr
}

Received January $6^{\text {th }}, 2012$; revised February $10^{\text {th }}, 2012$; accepted February $28^{\text {th }}, 2012$

\begin{abstract}
Web technology is changing rapidly every day and the Internet has become a lifestyle for people all over the world. It is obvious that the life style of societies is in a process of change, as new habits are acquired. Even though Internet use is one of the new social habits, it is one of the most important factors that induce this change as regards the convenience it brings to communication and other areas. The widespread use of Internet implies the idea that it can also be more widely used for educational purpose. Since chemistry teachers have a very important function in education, the determination of teachers' attitude towards Internet use is also important. In the literature it is possible to see many studies on teacher candidates' attitude towards Internet use; however studies on appointed teachers' attitude are not very common. In our study, which aims to determine the attitude of appointed chemistry teachers according to different variables, we used the Internet use attitude scale. Participant teacher's attitude towards Internet use was analyzed and interpreted according to the variables of gender, years on the job, type of school at which they are teaching, and duration of their weekly Internet use. It was seen that a vast majority of the teachers have personal computers, they connect to Internet at home and have positive attitude towards Internet use. It was also seen that female teachers have more positive attitude than male teachers in use of Internet for social interaction and communication.
\end{abstract}

Keywords: Internet Use; Internet Attitude; Chemistry Teachers; Teachers Opinions

\section{Introduction}

Web technology is changing rapidly every day and the Internet has become a lifestyle for people all over the world (Chen et al., 2011). It is obvious that the life style of societies is in a process of change, as new habits are acquired. Even though Internet use is one of the new social habits, it is one of the most important factors that induce this change as regards the convenience it brings to communication and other areas. For instance radio has reached 50 million listeners in 38 years' time; Internet on the other hand has reached this number in only 4 years (Lynch, 1998). Today Internet is used in teaching, research, social interaction, communication and exchange of information (Odabaş1 et al., 2007).

It is inevitable that teachers adapt themselves to the changes in the society; and adapt the new technology to their lives and teaching processes. Internet, which is a part of life with its informative, communicative, educational and entertaining functions, is more widely used by children and teens, who can adapt themselves more easily to Internet compared to adults (Tuncer, 2000). This can be regarded as an opportunity for the teachers. Teachers can ensure that students utilize Internet more widely for educational and teaching purposes. That is why the attitude of teachers towards Internet is important; as teachers are role models for the students and the society in general. The existence of Internet is visible in every aspect of life; personal and professional.

Efforts to utilize Internet more effectively in teaching are directly related to teachers' being information literate. Informa- tion literacy of teachers is expressed as "skills to gather, analyze, organize and present information" by Erdem and Akkoyunlu (2002). The view of "the Internet opens classrooms to the world, the Internet opens the world to classrooms" by Joo (1999) also suggests the importance that teachers should place on use of Internet in teaching environments and processes. It was also suggested that experiments can be carried out in analytical chemistry labs by means of teleconference and multimedia teaching materials via Internet (Zimmerer et al., 2003). The underlying idea for this suggestion is to minimize the laboratory accidents. An accident at a university chemistry laboratory proves that this suggestion cannot be underestimated (Hürriyet, 2010).

The higher the level of teachers to command technology is, the higher the level of teachers to use this technology in their courses will be (Becker, 1999). That's why it is important to determine the attitude of teachers towards a modern technological tool such as Internet.

When the related literature was reviewed (Teo, 2008; Lenhart et al., 2010; Schrader et al., 2003; Okay, 2010; İşman \& Dabaj, 2004; Luan et al., 2005; Birişci et al., 2009; Arslan \& Erdoğan, 2006; Yalçınalp \& Aşkar, 2003; Usta et al., 2007), it was seen that there are many studies on the use of Internet by students, but few on the use of Internet by teachers (Rowand, 2000; Wallace, 2004).

The main purpose of this study is to determine the state of Internet use as a result of the advances in educational and communication technologies by chemistry teachers, who are at 
the core of chemistry education, as well as to disclose their attitude towards Internet use and to determine their attitude towards Internet use as regards different variables.

The aim of this study is to determine the Internet attitude and Internet use of high school chemistry teachers, who are at the core of chemistry education.

\section{Method}

In the study descriptive model being one of the research methods, is used in order to determine the attitude of chemistry teachers towards Internet use.

Descriptive models are approaches that aim to describe an incident in the way it exists or used to exist. The incident that needs to be known exists and it is out there. The important issue is to observe it in an appropriate way and to detect it (Karasar, 1994).

The data of the study were collected by means of "Internet Use Attitude Scale" developed by Tavşancil and Keser (2002). The reliability coefficient (Cronbach's Alpha) of the scale is found to be 0.71 for this study. The Cronbach's Alpha reliability coefficient of the original scale is 0.89 . The data were then analyzed and interpreted by means of SPSS 15.0.

In the analysis of data about the demographic properties of teachers' frequency and percentage values were used. Independent sample t test was used in order to determine whether there is a significant difference among teachers' attitude as regards their gender and title. One way ANOVA was used in order to determine whether there is a significant difference among teachers' attitude as regards their years on the job, type of school at which they teach and duration of weekly use of Internet. Reliability level is $p=0.05$.

First, confirm that you have the correct template for your paper size. This template has been tailored for output on the custom paper size $(21 \mathrm{~cm} \times 28.5 \mathrm{~cm})$.

\section{Sample}

The sample of the study consists of 97 chemistry teachers, who took part in the Chemistry Lesson Teaching Programs Course numbered 279 that was determined by In-Service Training Department of Ministry of National Education. The teachers were selected randomly. Table 1 shows type of the school served, years on the job, gender and title of teachers.

As seen by Table 1, the majority of teachers that took part in the study are relatively junior in the profession. The ratio of the teachers who have been on the job for $1-15$ years is $71.1 \%$. It was also found out that $96.9 \%(\mathrm{~N}=94)$ of the teachers have computer at home; $87.6 \%(\mathrm{~N}=85)$ connect to Internet at home; $12 \%(\mathrm{~N}=12)$ connect to Internet at school. The ratio of the teachers who have been using Internet for at least 6 years is found to be $90.6 \%(\mathrm{~N}=89)$. This situation is associated with the fact that a vast majority of the teachers are at a young age group. $38.1 \%(\mathrm{~N}=37)$ use Internet for at least 10 hours a week; $61.9 \%(\mathrm{~N}=63)$ use it for $1-7$ hours a week.

\section{Data Collection Tool}

The attitude of teachers towards Internet use was determined by "Internet Use Attitude Scale" developed by Tavşancil and Keser (2002); personal information was collected by "Personal Information Survey". In the attitude scale there are 31 items; of
Table 1.

Demographic properties of teachers that took part in the study.

\begin{tabular}{|c|c|c|c|}
\hline & Property & $\mathrm{N}$ & $\%$ \\
\hline \multirow{2}{*}{ Gender } & Male & 62 & 63.9 \\
\hline & Female & 35 & 36.1 \\
\hline \multirow{4}{*}{$\begin{array}{l}\text { Type of the school } \\
\text { served }\end{array}$} & Natural Sciences High School & 13 & 13.4 \\
\hline & Anatolian High School & 40 & 41.2 \\
\hline & General High School & 18 & 18.6 \\
\hline & Vocational High School & 26 & 26.8 \\
\hline \multirow{4}{*}{ Years on the job } & $1-5$ & 1 & 1.0 \\
\hline & $6-10$ & 23 & 23.7 \\
\hline & $11-15$ & 45 & 46.4 \\
\hline & $16-+$ & 28 & 28.9 \\
\hline \multirow{4}{*}{ Title } & Head teacher & 0 & 0.0 \\
\hline & Expert teacher & 27 & 27.8 \\
\hline & Teacher & 70 & 72.2 \\
\hline & Intern teacher & 0 & 0.0 \\
\hline
\end{tabular}

which 7 are negative and 26 are positive; plus 6 factors. These factors are "use of Internet in teaching, in research, social interaction, enjoying of the use in teaching, use in communication and in exchange of information".

\section{Findings}

Below there is a summary of the findings from the study and some remarks on them. In the study the attitude of teachers towards Internet used is analyzed statistically according to their gender by an independent sample t test. The results are given in Table 2.

It is seen from Table 2 that male teachers have a more positive attitude than female teachers towards use of Internet in teaching $(\bar{X}=2.15)$. The relation between the mean of total attitude points of the teachers towards use of Internet in teaching and their gender was analyzed and it was seen that there is a significant difference $(\mathrm{t}(95)=2.987 ; p<0.05)$. This result shows that there is a significant relation between the gender and the use of Internet in teaching.

It is known that the demand for social network sites has increased particularly due to the fast spread of Internet use (Lenhart et al., 2010). One of the factors in the Internet attitude scale developed by Tavşancil and Keser (2002) is about the use of Internet is social interaction. It is seen by Table 2 that the mean of total attitude score of female teachers in using Internet in social interaction is $\bar{X}=3.41$, that of male teachers is $\bar{X}=$ 2.90; which implies that female teachers use Internet more often for social interaction. It is also seen that there is a significant difference $(\mathrm{t}(95)=2.667 ; p<0.05)$ between gender and the mean of total attitude points in use of Internet in social interaction.

According to Table 2 there is no significant difference between gender and the factor "enjoying the use of Internet in tea- 
Table 2.

Independent sample $\mathrm{t}$ test analysis results according to gender.

\begin{tabular}{|c|c|c|c|c|c|c|c|c|c|}
\hline \multirow{2}{*}{ Factor } & \multirow{2}{*}{ Gender } & \multirow{2}{*}{$\mathrm{F}$} & \multirow{2}{*}{$\bar{X}$} & \multirow{2}{*}{ SD } & \multicolumn{2}{|c|}{ Levene Test } & \multirow{2}{*}{ df } & \multirow{2}{*}{$\mathrm{t}$} & \multirow{2}{*}{$p$} \\
\hline & & & & & $\mathrm{F}$ & $p$ & & & \\
\hline \multirow[b]{2}{*}{ Use of Internet in teaching } & Female & 35 & 1.80 & 0.49 & \multirow[b]{2}{*}{0.007} & \multirow[b]{2}{*}{0.935} & \multirow[b]{2}{*}{95} & \multirow[b]{2}{*}{2.987} & \multirow[b]{2}{*}{0.004} \\
\hline & Male & 62 & 2.15 & 0.58 & & & & & \\
\hline \multirow[b]{2}{*}{ Use of Internet in research } & Female & 35 & 2.74 & 0.28 & \multirow[b]{2}{*}{2.349} & \multirow[b]{2}{*}{0.129} & \multirow[b]{2}{*}{95} & \multirow[b]{2}{*}{0.865} & \multirow[b]{2}{*}{0.389} \\
\hline & Male & 62 & 2.80 & 0.36 & & & & & \\
\hline \multirow{2}{*}{ Use of Internet in social interaction } & Female & 35 & 3.41 & 0.81 & \multirow[b]{2}{*}{0.819} & \multirow[b]{2}{*}{0.368} & \multirow[b]{2}{*}{95} & \multirow[b]{2}{*}{2.667} & \multirow[b]{2}{*}{0.009} \\
\hline & Male & 62 & 2.90 & 0.96 & & & & & \\
\hline \multirow{2}{*}{ Enjoying of the use of Internet in teaching } & Female & 35 & 2.95 & 0.51 & \multirow{2}{*}{0.240} & \multirow{2}{*}{0.625} & \multirow{2}{*}{95} & \multirow{2}{*}{0.503} & \multirow{2}{*}{0.616} \\
\hline & Male & 62 & 3.00 & 0.51 & & & & & \\
\hline \multirow{2}{*}{ Use of Internet in communication } & Female & 35 & 3.33 & 0.41 & \multirow{2}{*}{0.603} & \multirow{2}{*}{0.439} & \multirow{2}{*}{95} & & \\
\hline & Male & 62 & 3.00 & 0.44 & & & & 3.586 & 0.001 \\
\hline & Female & 35 & 2.34 & 0.71 & & & & & \\
\hline Use of Internet in exchange of information & Male & 62 & 2.27 & 0.76 & 0.034 & 0.855 & 95 & 0.393 & 0.696 \\
\hline
\end{tabular}

Note: $p=0.05$.

ching" $(\mathrm{t}(95)=0.503 ; p>0.05)$.

Furthermore when Table 2 is analyzed, it is seen that there are similar properties between use of Internet in communication by female and male teachers, as in use of Internet by social interaction in such a way that the mean of total attitude score of female teachers in using Internet in communication $(\bar{X}=3.33)$ is higher than that of male teachers $(\bar{X}=3.00)$. It can be concluded that female teachers have more positive attitude in use of Internet in communication than male teachers. It is also seen by Table 2 that there is a significant difference $(\mathrm{t}(95)=3.586$; $p<0.05$ ) between gender and the mean of total attitude points of use of Internet in communication.

Similarly Table 2 shows that there is not a significant difference between gender and the mean of total attitude points in use of Internet in exchange of information $(\mathrm{t}(95)=0.393 ; p>$ $0.05)$.

In the study we also aimed to analyze the attitude of teachers towards use of Internet as regards the type of school they teach at, and we applied one way ANOVA. The results are given in Table 3.

When Table 3 is analyzed, it can be seen that the mean of the total attitude points towards use of Internet in teaching is the highest ( $\bar{X}=2.17$ ) for the chemistry teachers teaching at general high schools. There is no statistically significant difference between type of school served and the mean of total attitude points towards use of Internet in teaching $(\mathrm{F}(3.93)=0.980 ; p>$ $0.05)$.

The mean of the total attitude points towards use of Internet in research is the highest $(\bar{X}=2.85)$ for the chemistry teachers teaching at Anatolian high schools. There is no statistically significant difference between type of school served and the mean of total attitude points towards use of Internet in research $(\mathrm{F}(3.93)=1.516 ; p>0.05)$.

The mean of the total attitude points towards use of Internet in social interaction is the highest $(\bar{X}=3.19)$ for the chemistry teachers teaching at Anatolian high schools. There is no statistically significant difference between type of school served and the mean of total attitude points towards use of Internet in social interaction $(\mathrm{F}(3.93)=0.791 ; p>0.05)$.

The mean of the total attitude points towards enjoying the use of Internet in teaching is the highest $(\bar{X}=3.06)$ for the chemistry teachers teaching at natural sciences high schools. There is no statistically significant difference between type of school served and the mean of total attitude points towards enjoying the use of Internet in teaching $(\mathrm{F}(3.93)=0.313 ; p>$ $0.05)$.

The mean of the total attitude points towards use of Internet in communication is the highest $(\bar{X}=3.23)$ for the chemistry teachers teaching at Anatolian high schools. Hence it can be said that teachers at Anatolian high schools have more positive attitude towards enjoying the use of Internet in communication. There is a significant difference between type of school served and the mean of total attitude points towards use of Internet in communication $(\mathrm{F}(3.93)=4.622 ; p<0.05)$. In order to find out from which group this difference results; we applied Scheffe analysis in ANOVA and the results are summarized in the table.

Table 4 shows that there is a significant difference between teachers serving at natural sciences high schools and teachers serving at public high schools in total attitude points in use of Internet in communication $(p>0.05)$. There is no significant difference between teachers serving at natural sciences high schools and teachers serving at Anatolian high schools in total attitude points in use of Internet in communication $(p<0.05)$. These results suggest that there is a significant difference in favour of teachers serving at Anatolian high schools and vocational high schools in use of Internet in communication.

Table 3 shows that the mean of the total attitude points towards use of Internet in exchange of information is the highest $(\bar{X}=2.43)$ for the chemistry teachers teaching at vocational 
Table 3.

One way ANOVA for the attitude of teachers towards use of Internet as regards type of school they teach at.

\begin{tabular}{|c|c|c|c|c|c|c|c|c|c|}
\hline Factor & Type of school & $\mathrm{n}$ & $\bar{X}$ & SD & $\begin{array}{l}\text { Source of } \\
\text { variance }\end{array}$ & $\begin{array}{l}\text { Sum of } \\
\text { squares }\end{array}$ & $\mathrm{df}$ & $\mathrm{F}$ & $p$ \\
\hline \multirow{3}{*}{ Use of Internet in teaching } & $\begin{array}{c}\text { Natural Sciences High School } \\
\text { Anatolian High School }\end{array}$ & 13 & $\begin{array}{l}2.09 \\
2.04\end{array}$ & $\begin{array}{l}0.55 \\
0.55\end{array}$ & $\begin{array}{c}\text { Between } \\
\text { groups }\end{array}$ & 0.965 & 3 & \multirow{3}{*}{0.980} & \multirow{3}{*}{0.406} \\
\hline & General High School & 18 & 2.17 & 0.67 & \multirow[b]{2}{*}{$\begin{array}{l}\text { Within } \\
\text { group }\end{array}$} & \multirow[b]{2}{*}{30.533} & \multirow[b]{2}{*}{93} & & \\
\hline & Vocational High School & 26 & 1.88 & 0.55 & & & & & \\
\hline \multirow{4}{*}{ Use of Internet in research } & Natural Sciences High School & 13 & 2.73 & 0.32 & \multirow{2}{*}{$\begin{array}{c}\text { Between } \\
\text { groups }\end{array}$} & \multirow{2}{*}{0.493} & \multirow{2}{*}{3} & \multirow{4}{*}{1.516} & \multirow{4}{*}{0.215} \\
\hline & Anatolian High School & 40 & 2.85 & 0.31 & & & & & \\
\hline & General High School & 18 & 2.67 & 0.38 & \multirow[b]{2}{*}{$\begin{array}{l}\text { Within } \\
\text { group }\end{array}$} & \multirow[b]{2}{*}{10.077} & \multirow[b]{2}{*}{93} & & \\
\hline & Vocational High School & 26 & 2.76 & 0.32 & & & & & \\
\hline \multirow{3}{*}{$\begin{array}{l}\text { Use of Internet in social } \\
\text { interaction }\end{array}$} & Natural Sciences High School & 13 & 3.17 & 0.95 & \multirow{2}{*}{$\begin{array}{c}\text { Between } \\
\text { groups }\end{array}$} & \multirow{2}{*}{2.086} & \multirow{2}{*}{3} & \multirow{3}{*}{0.791} & \multirow{3}{*}{0.502} \\
\hline & Anatolian High School & 40 & 3.19 & 0.87 & & & & & \\
\hline & $\begin{array}{l}\text { General High School } \\
\text { Vocational High School }\end{array}$ & 18 & $\begin{array}{l}3.15 \\
2.85\end{array}$ & $\begin{array}{l}1.05 \\
0.96\end{array}$ & $\begin{array}{l}\text { Within } \\
\text { group }\end{array}$ & 81.794 & 93 & & \\
\hline \multirow{2}{*}{$\begin{array}{l}\text { Enjoying of the use of } \\
\text { Internet in teaching }\end{array}$} & $\begin{array}{c}\text { Natural Sciences High School } \\
\text { Anatolian High School }\end{array}$ & 13 & 3.06 & $\begin{array}{l}0.57 \\
0.48\end{array}$ & $\begin{array}{c}\text { Between } \\
\text { groups }\end{array}$ & 0.246 & 3 & \multirow{2}{*}{0.313} & \multirow{2}{*}{0.816} \\
\hline & $\begin{array}{l}\text { General High School } \\
\text { Vocational High School }\end{array}$ & 18 & 2.92 & $\begin{array}{l}0.64 \\
0.43\end{array}$ & $\begin{array}{l}\text { Within } \\
\text { group }\end{array}$ & 24.356 & 93 & & \\
\hline in & $\begin{array}{c}\text { Natural Sciences High School } \\
\text { Anatolian High School }\end{array}$ & 13 & $\begin{array}{l}2.77 \\
3.23\end{array}$ & $\begin{array}{l}0.35 \\
0.40\end{array}$ & $\begin{array}{c}\text { Between } \\
\text { groups }\end{array}$ & 2.629 & 3 & & \\
\hline communication & General High School & 18 & 2.99 & 0.60 & & & & 4.022 & 0.005 \\
\hline & Vocational High School & 26 & 3.22 & 0.40 & group & 17.633 & 93 & & \\
\hline & Natural Sciences High School & 13 & 2.42 & 0.71 & Between & 2504 & 3 & & \\
\hline Use of Internet in exchange & Anatolian High School & 40 & 2.31 & 0.78 & groups & & & & \\
\hline 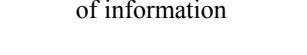 & General High School & 18 & 1.97 & 0.63 & Within & 10600 & 02 & 1.010 & 0.191 \\
\hline & Vocational High School & 26 & 2.43 & 0.72 & group & & & & \\
\hline
\end{tabular}

Note: $p=0.05$.

Table 4.

Scheffe analysis as regards use of Internet in communication.

\begin{tabular}{cccc}
\hline (I) Type of school & (J) Type of school & $\begin{array}{c}\text { (I - J) Difference be- } \\
\text { tween significance levels }\end{array}$ & $p$ \\
\hline & $\begin{array}{c}\text { Anatolian high } \\
\text { school }\end{array}$ & $0.45577\left(^{*}\right)$ & 0.017 \\
$\begin{array}{c}\text { Natural sciences } \\
\text { high school }\end{array}$ & $\begin{array}{c}\text { General high } \\
\text { school } \\
\text { Vocational high } \\
\text { school }\end{array}$ & 0.21688 & 0.601 \\
& $0.45192\left(^{*}\right)$ & 0.030 \\
\hline
\end{tabular}

Note: $p=0.05$. high schools. There is no significant difference between type of school served and the mean of total attitude points towards use of Internet in exchange of information $(\mathrm{F}(3.93)=1.618 ; p>$ $0.05)$.

In the study we also aimed to analyze the attitude of teachers towards use of Internet as regards the years they've been on the job. For this analysis we applied one way ANOVA to the data and the results are given in Table 5 .

When Table 5 is analyzed, it is seen that the mean of the total attitude points towards use of Internet in teaching is the highest $(\bar{X}=2.20)$ for the chemistry teachers, who have been on the job for 16 years or more. There is no statistically significant difference between years on the job and the mean of total attitude points towards use of Internet in teaching $(\mathrm{F}(3.93)$ 
Table 5.

Single factor ANOVA analysis for attitude towards Internet use as regards years on the job variable.

\begin{tabular}{|c|c|c|c|c|c|c|c|c|c|}
\hline Factor & Years on the job & $\mathrm{F}$ & $\bar{X}$ & $\mathrm{SD}$ & Source of variance & Sum of squares & $\mathrm{df}$ & $\mathrm{F}$ & $p$ \\
\hline \multirow{3}{*}{ Use of Internet in teaching } & $6-10$ & 24 & 2.02 & 0.74 & Between groups & 1.299 & 2 & \multirow{3}{*}{2.021} & \multirow{3}{*}{0.138} \\
\hline & $11-15$ & 45 & 1.92 & 0.48 & & & & & \\
\hline & $16-+$ & 28 & 2.20 & 0.53 & Within group & 30.200 & 94 & & \\
\hline \multirow{3}{*}{ Use of Internet in research } & $6-10$ & 24 & 2.81 & 0.33 & Between groups & 0.048 & 2 & \multirow{3}{*}{0.215} & \multirow{3}{*}{0.807} \\
\hline & $11-15$ & 45 & 2.76 & 0.32 & & & & & \\
\hline & $16-+$ & 28 & 2.79 & 0.36 & Within group & 10.522 & 94 & & \\
\hline \multirow{3}{*}{$\begin{array}{l}\text { Use of Internet in social } \\
\text { interaction }\end{array}$} & $6-10$ & 24 & 3.40 & 1.01 & Between groups & 4.546 & 2 & \multirow{3}{*}{2.693} & \multirow{3}{*}{0.073} \\
\hline & $11-15$ & 45 & 3.10 & 0.95 & & & & & \\
\hline & $16-+$ & 28 & 2.80 & 0.78 & Within group & 79.334 & 94 & & \\
\hline \multirow{3}{*}{$\begin{array}{l}\text { Enjoying of the use of Internet } \\
\text { in teaching }\end{array}$} & $6-10$ & 24 & 2.99 & 0.50 & Between groups & 0.529 & 2 & \multirow{3}{*}{1.034} & \multirow{3}{*}{0.360} \\
\hline & $11-15$ & 45 & 3.05 & 0.48 & & & & & \\
\hline & $16-+$ & 28 & 2.88 & 0.54 & Within group & 24.072 & 94 & & \\
\hline \multirow{3}{*}{ Use of Internet in communication } & $6-10$ & 24 & 3.31 & 0.49 & Between groups & 1.285 & 2 & \multirow{3}{*}{3.183} & \multirow{3}{*}{0.046} \\
\hline & $11-15$ & 45 & 3.03 & 0.41 & & & & & \\
\hline & $16-+$ & 28 & 3.10 & 0.47 & Within group & 18.976 & 94 & & \\
\hline \multirow{3}{*}{$\begin{array}{l}\text { Use of Internet in exchange } \\
\text { of information }\end{array}$} & $6-10$ & 24 & 2.38 & 0.82 & Between groups & .938 & 2 & \multirow{3}{*}{0.858} & \multirow{3}{*}{0.427} \\
\hline & $11-15$ & 45 & 2.35 & 0.74 & & & & & \\
\hline & $16-+$ & 28 & 2.14 & 0.66 & Within group & 51.354 & 94 & & \\
\hline
\end{tabular}

Note: $p=0.05$.

$=2.021 ; p>0.05)$.

The mean of the total attitude points towards use of Internet in research is the highest $(\bar{X}=2.79)$ for the chemistry teachers, who have been on the job for 16 years and more. There is no significant difference between years on the job and the mean of total attitude points towards use of Internet in research $(\mathrm{F}(3.93)$ $=0.215 ; p>0.05$ ).

The mean of the total attitude points towards use of Internet in social interaction is the highest $(\bar{X}=3.40)$ for the chemistry teachers, who have been on the job for $6-10$ years. There is no statistically significant difference between years on the job and the mean of total attitude points towards use of Internet in social interaction $(\mathrm{F}(3.93)=2.693 ; p>0.05)$. The mean of the total attitude points towards use of Internet in enjoying of the use of Internet in teaching is the highest $(\bar{X}=3.05)$ for the chemistry teachers, who have been on the job for 11 - 15 years. There is no statistically significant difference between years on the job and the mean of total attitude points towards enjoying of the use of Internet in teaching $(\mathrm{F}(3.93)=1.034 ; p>0.05)$.

The mean of the total attitude points towards use of Internet in communication is the highest $(\bar{X}=3.31)$ for the chemistry teachers, who have been on the job for $6-10$ years. Hence teachers, who have been on the job for $6-10$ years have more positive attitude towards use of Internet in communication. There is a significant difference between years on the job and the mean of total attitude points towards use of Internet in communication $(\mathrm{F}(3.93)=3.183 ; p<0.05)$. In order to find out among which group this difference results from, we applied Scheffe analysis in ANOVA and the results are summarized in Table 6 below.

When Table 5 is analyzed, it is seen that the mean of the total attitude points towards use of Internet in exchange of information is the highest $(\bar{X}=2.38)$ for the chemistry teachers, who have been on the job for 6 - 10 years. There is no significant difference between years on the job and the mean of total attitude points towards use of Internet in exchange of information $(\mathrm{F}(3.93)=0.858 ; p>0.05)$.

In the study we also aimed to analyze the attitude of teachers towards use of Internet as regards the weekly use of Internet variable. For this analysis we applied one way ANOVA to the data and the results are given in Table 7.

When Table 7 is analyzed, it is seen that the mean of the total attitude points towards use of Internet in teaching is the

Table 6.

Scheffe analysis towards use of Internet in communication.

\begin{tabular}{cccc}
\hline $\begin{array}{c}\text { (I) Years on } \\
\text { the job }\end{array}$ & $\begin{array}{c}\text { (J) Years on the } \\
\text { job }\end{array}$ & $\begin{array}{c}\text { (I - J) Difference between } \\
\text { significance levels }\end{array}$ & $p$ \\
\hline $6-10$ & $11-15$ & $0.28472\left(^{*}\right)$ & 0.048 \\
& $16-+$ & 0.21429 & \\
\hline
\end{tabular}

Note: $p=0.05$. 
Table 7.

One way ANOVA for the attitude of teachers towards use of Internet as regards the weekly use of Internet variable.

\begin{tabular}{|c|c|c|c|c|c|c|c|c|c|}
\hline Factor & Duration/hours & $\mathrm{n}$ & $\bar{X}$ & $\mathrm{SD}$ & Source of variance & Sum of squares & df & $\mathrm{F}$ & $p$ \\
\hline \multirow{4}{*}{ Use of Internet in teaching } & $1-3$ & 19 & 2.17 & 0.71 & \multirow{3}{*}{ Between groups } & \multirow{2}{*}{1.230} & \multirow{2}{*}{3} & \multirow{4}{*}{1.259} & \multirow{4}{*}{0.293} \\
\hline & $4-6$ & 19 & 2.16 & 0.63 & & & & & \\
\hline & $7-9$ & 22 & 1.91 & 0.42 & & \multirow[b]{2}{*}{30.268} & & & \\
\hline & $10-+$ & 37 & 1.95 & 0.54 & Within groups & & 93 & & \\
\hline \multirow{5}{*}{ Use of Internet in research } & $1-3$ & 19 & 2.79 & 0.28 & \multirow[b]{2}{*}{ Between groups } & \multirow[b]{2}{*}{0.040} & \multirow[b]{2}{*}{3} & \multirow{5}{*}{0.119} & \multirow{5}{*}{0.949} \\
\hline & $4-6$ & 19 & 280 & 0.40 & & & & & \\
\hline & & & & & \multirow{3}{*}{ Within groups } & \multirow{3}{*}{10.530} & & & \\
\hline & $7-9$ & 22 & 2.79 & 0.21 & & & \multirow{2}{*}{93} & & \\
\hline & $10-+$ & 37 & 2.75 & 0.38 & & & & & \\
\hline \multirow{4}{*}{$\begin{array}{l}\text { Use of Internet in social } \\
\text { interaction }\end{array}$} & $1-3$ & 19 & 3.53 & 0.85 & \multirow{2}{*}{ Between groups } & \multirow{2}{*}{5.071} & \multirow{2}{*}{3} & \multirow{4}{*}{1.995} & \multirow{4}{*}{0.120} \\
\hline & $4-6$ & 19 & 3.09 & 0.98 & & & & & \\
\hline & $7-9$ & 22 & 3.02 & 0.92 & \multirow[b]{2}{*}{ Within groups } & \multirow[b]{2}{*}{78.809} & \multirow[b]{2}{*}{93} & & \\
\hline & $10-+$ & 37 & 2.90 & 0.93 & & & & & \\
\hline \multirow{4}{*}{$\begin{array}{l}\text { Enjoying of the use of } \\
\text { Internet in teaching }\end{array}$} & $1-3$ & 19 & 3.37 & 0.51 & \multirow{3}{*}{ Between groups } & \multirow[b]{2}{*}{3.497} & \multirow[b]{2}{*}{3} & & \\
\hline & $4-6$ & 19 & 288 & 033 & & & & & \\
\hline & $7-9$ & 22 & 2.88 & 0.48 & & & & 5.137 & 0.002 \\
\hline & $10-+$ & 37 & 291 & 0.52 & Within groups & 21.105 & 93 & & \\
\hline & $1-3$ & 19 & 3.12 & 0.46 & & & & & \\
\hline & $4-6$ & 19 & 3.11 & 0.53 & Between groups & 0.215 & 3 & & \\
\hline communication & $7-9$ & 22 & 3.05 & 0.38 & & & & 0.332 & 0.802 \\
\hline & $10-+$ & 37 & 3.17 & 0.48 & Within groups & 20.047 & 93 & & \\
\hline & $1-3$ & 19 & 2.55 & 0.75 & & & & & \\
\hline & $4-6$ & 19 & 233 & 0.79 & Between groups & 2.316 & 3 & & \\
\hline of information & $7-9$ & 22 & 2.08 & 075 & & & & 1.437 & 0.237 \\
\hline & $10-+$ & 37 & 2.28 & 0.68 & Within groups & 49.975 & 93 & & \\
\hline
\end{tabular}

Note: $p=0.05$.

highest $(\bar{X}=2.17)$ for the chemistry teachers, who use Internet for 1 - 3 hours/week. There is no significant difference between the duration of weekly use of Internet and the mean of total attitude points towards the use of Internet in teaching $(\mathrm{F}(3.93)=$ $1.259 ; p>0.05)$.

The mean of the total attitude points towards the use of Internet in research is the highest $(\bar{X}=2.80)$ for the chemistry teachers, who use Internet for $4-6$ hours/week. There is no significant difference between the duration of weekly use of Internet and the mean of total attitude points towards the use of Internet in research $(\mathrm{F}(3.93)=0.119 ; p>0.05)$.

The mean of the total attitude points towards the use of Internet in social interaction is the highest $(\bar{X}=3.53)$ for the chemistry teachers, who use Internet for 1 - 3 hours/week. There is no significant difference between the duration of weekly use of Internet and the mean of total attitude points towards the use of Internet in social interaction $(\mathrm{F}(3.93)=$ 1.995; $p>0.05)$.
The mean of the total attitude points towards enjoying of the use of Internet in teaching is the highest $(\bar{X}=3.37)$ for the chemistry teachers, who use Internet for 1 - 3 hours/week. Hence teachers, who use Internet for 1 - 3 hours/week have more positive attitude towards enjoying of the use of Internet in teaching. There is a significant difference between the duration of weekly use of Internet and total attitude points towards enjoying of the use of Internet in teaching $(\mathrm{F}(3.93)=5.137 ; p<$ $0.05)$. In order to find out among which group this difference results from, we applied Scheffe analysis in ANOVA and the results are summarized in Table 8.

It is understood by Table 8 that there is no significant difference in enjoying of the use of Internet in teaching among teachers, who use the Internet for $1-3$ hours/week and teachers who use the Internet for $4-6$, or 7 - 9 or 10 hours or more/week $(p<0.05)$. The results suggest that there is a significant difference in favour of teachers, who use the Internet for 1 - 3 hours/ week. 
Table 8.

Scheffe analysis towards enjoying of the use of Internet in teaching.

\begin{tabular}{cccc}
\hline $\begin{array}{c}\text { (I) Duration of } \\
\text { weekly use (hours) }\end{array}$ & $\begin{array}{c}\text { (J) Duration of } \\
\text { weekly use (hours) }\end{array}$ & $\begin{array}{c}\text { (I - J) Difference between } \\
\text { significance levels }\end{array}$ & $p$ \\
\hline $4-6$ & $0.48684\left(^{*}\right)$ & 0.024 \\
1 - 3 & $7-9$ & $0.49342\left(^{*}\right)$ & 0.015 \\
& $10-+$ & $0.46302\left(^{*}\right)$ & 0.011 \\
\hline
\end{tabular}

Note: $p=0.05$.

When Table 7 is analyzed, it is seen that the mean of the total attitude points towards use of Internet in communication is the highest $(\bar{X}=3.17)$ for the chemistry teachers, who use Internet for 10 hours or more during the week. There is no significant difference between the duration of weekly use of Internet and the mean of total attitude points towards the use of Internet in communication $(\mathrm{F}(3.93)=0.332 ; p>0.05)$.

The mean of the total attitude points towards use of Internet in exchange of information is the highest $(\bar{X}=2.55)$ for the chemistry teachers, who use Internet for 1 - 3 hours/week. There is no significant difference between the duration of weekly use of Internet and the mean of total attitude points towards the use of Internet in exchange of information $(\mathrm{F}(3.93)$ $=1.437 ; p>0.05$ ).

\section{Results and Discussions}

In this study, which aims to determine the attitude of chemistry teachers towards use of Internet, we have reached the following results:

One of the remarkable results of the study is that the teachers in general have positive attitude towards use of Internet in teaching. We consider the fact that the technological advances have been reflected upon teaching materials within the recent years increases the positive attitude towards use on Internet, which is also a technological product, in teaching. Moreover it is also understood that "learning from Internet" has also speeded up recently with the fact that many encyclopedic information is available on Internet. It is an incontrovertible fact that Internet will be more evident in teaching by the increase of distance education practices. Thus Okay (2010) found out in a study about use of Internet by teacher candidates that Internet is intensely used for homework and research. Luan et al. (2005) found out that Internet is mostly used in obtaining information by university students. Similarly Usta, Bozdoğan and Y1ldırım (2007) found in their study that students mostly use Internet for educational purposes. An interesting finding is that the teachers, who have been on the job for 21 years or more, have the most positive attitude towards use of Internet in teaching.

The reason of this may be the tendency of experienced teachers to use Internet more functionally and usefully. Karaman and Açikyıldız (2006) found in their study on attitude of chemistry teacher candidates towards use of Internet sources that the teacher candidates have positive attitude towards use of Internet in generating teaching materials.

The most remarkable finding of the study is that female teachers have more positive attitude than male teachers in use of Internet in social interaction and communication. This finding is in line with the use of Internet in communication. That is to say female teachers have more positive attitude than male teachers towards use of Internet in communication. Teachers, who have been on the job for $1-6$ years have the most positive attitude towards use of Internet in social interaction as regards years on the job variable (see Table 5).

In today's world where unsynchronized and Internet based education-teaching practices have become more common, the attitude of teachers towards use of Internet in applied subjects such as chemistry, is an important factor that needs to be taken into account when applying these models.

Our study can be considered to elucidate practices to be developed and further studies to be carried on.

\section{REFERENCES}

Arslan, A., \& Erdoğan, Y. (2006). Investigating the correlations between Turkish students' personality characteristics and Internet attitudes. Proceedings of the 5th WSEAS International Conference on Education and Educational Technology, Tenerife, 16-18 December 2006, 2833.

Becker, H. (1999). Internet use by teachers: Conditions of professional use and teacher-directed student use. Irvine, CA: Center for Research on Information Technology and Organizations.

Birişci, S., Metin, M., \& Karakaş, M. (2009). Prospective elemantary teachers' attitudes toward computer and Internet use: A sample from Turkey. World Applied Sciences Journal, 6, 1433-1440.

Chen, V. J., Lin, C., Yen, C. D., \& Linn, K. P. (2011). The interaction effects of familiarity, breadth and media usage on web browsing experience. Computers in Human Behavior, 27, 2141-2152. doi:10.1016/j.chb.2011.06.008

Erdem, M., \& Akkoyunlu, B. (2002). Information literacy skills and characteristics of learning environments on equipping students with these skills. Journal of Qafqaz University, 9, 125-132.

Hürriyet, A. (2010). Poisoned gas panic in Marmara University. URL (last checked 15 October 2012). http://www.hurriyet.com.tr/gundem/16052842.asp

İşman, A., \& Dabaj, F. (2004). Attitudes of students towards Internet. URL (last checked 15 August 2011). http://tojde.anadolu.edu.tr/tojde16/articles/dabaj.htm

Joo, J. E. (1999). Cultural issues of the Internet in classrooms. British Journal of Educational Technology, 30, 245-250. doi:10.1111/1467-8535.00113

Karaman, S., \& Açıkyıldız, M. (2006). Chemistry prospective teachers' attitudes toward using Internet resources and difficulties. Ahi Evran University Faculty of Education Journal, 7, 207-215.

Karasar, N. (2000). Scientific research methods-Term, scopes, tecniques. Ankara: Nobel Publication.

Lenhart, A., Purcell, K., Smith, A., \& Zickuhr, K. (2010). Social media $\&$ mobile Internet use among teens and young adults. Washington DC: Pew Research Center.

Luan, W. S., Fung, N. S., Nawawi, M., \& Hong, T. S. (2005). Experienced and inexperienced Internet users among pre-service teachers: Their use and attitudes toward the Internet. Educational Technology \& Society, 81, 90-103.

Lynch, O. (1998). All change please. Times Educational Supplement Online, 35 .

Odabaşı, H. F., Çoklar, A. N., \& Kabakçı, I. (2007). The new world: Internet-What are the responsibilities of parents in the new world. Aybastı Kabataş Symposium, 8, 1-9.

Okay, Ş. (2010). A research on investigation of Internet using purposes of technical teacher candidates. Electronic Journal of Machine Technologies, 7, 97-109.

Rowand, C. (2000). Teacher use of computers and the Internet in public schools. Washington DC: National Center for Education Statistics.

Schrader, P. G., Leu, D. J., Kinzer, C. K., Ataya, R., Teale, W. H., Labbo, L. D., \& Cammack, D. (2003). Using Internet delivered video cases, to support pre-service teachers' understanding of effective early literacy instruction: An exploratory study. Instructional Science, 31, 317-340. doi:10.1023/A:1024690111227 


\section{TEKEREK, O. ERCAN}

Tavşancıl, E., \& Keser, H. (2002). Developing a teachers using attitudes towards Internet scale. Educational Science and Practice, 1, 79-100.

Teo, T. (2008). Pre-service teachers' attitudes towards computer use: A Singapore survey. Australasian Journal of Educational Technology, 24, 413-424.

Tuncer, N. (2000). Internet use by children. Turkish Librarians, 14, $205-$ 212.

Usta, E., Bozdoğan, A. E., \& Yildırım, K. (2007). Evaluating elementary pre-service teachers' attitudes toward Internet use. Ahi Evran University Faculty of Education Journal, 8, 209-222.

Wallace, R. M. (2004). A framework for understanding teaching with the Internet. American Educational Research Journal, 41, 447-488. doi: $10.3102 / 00028312041002447$

Wong, S. L., Ng, S. F., Mokhtar N., \& Tang, S. H. (2005). Experienced and inexperienced Internet users among pre-service teachers: Their use and attitudes toward the Internet. Journal of Educational Technology \& Society, 8, 90-103.

Yalçınalp, S., \& Aşkar, P. (2003). Investigation of aims of information search of students Internet using style. The Turkish Online Journal of Educational Technology, 2, 100-107.

Zimmerer, C., Thiele, S., Salzer, R., Krauseneck, A., \& Koerndle, H. (2003). Internet teaching: Laboratory course in analytical chemistry. Microchimica Acta, 142, 153-159. doi:10.1007/s00604-003-0012-6 